\title{
Trade union and social rights as a part of human rights
}

\begin{abstract}
Human rights are the inalienable rights of all people, irreplaceable and inviolable. Second-generation human rights - political, social and cultural - guarantee a right to work, to organise in trade unions, to social security and to enjoy property. With their assistance, employees can assert their collective and social rights. The International Covenant on Economic, Social and Cultural Rights was adopted in 1966 and our country has ratified it twice. The influence that politics has on social and trade union rights cannot be neglected, while social and economic rights are interdependent with the political will of the country. The Republic of Serbia has passed legal norms which satisfy international standards but, unfortunately, it does not have the capacity to apply these laws adequately. Remembering that almost all rights of citizens are asserted with the help of strong trade unions and also that, with the creation of such conditions in Serbia, we send a clear picture that Serbia is mature and ready for the international community, this article reviews the current state of these processes.
\end{abstract}

Keywords: human rights, generations of rights, trade union rights, social rights, economic and political crisis, international covenants, trade union organisation, right to work, working conditions, political dependence

\section{Introduction}

Human rights, as a part of international public law, can be defined from a formal legal perspective as a body of principles, standards and norms which share the common goal of protecting human beings and their dignity, as well as of providing all the necessary living conditions that enable people to fulfil and enhance both their spiritual and biological needs.

Human rights represent a body of moral principles whose justifiability rests in moral concepts of humankind and human nature. We can therefore say that human rights are authentic, universal and inalienable. Everyone is entitled to human rights, regardless of their colour, nationality, ethnic affiliation or sex: people become a bearer of human rights by the very act of their birth.

Nevertheless, these rights are not unchangeable; they do tend to develop in compliance with changes of an international and, indirectly, the national political scene.

According to some theorists, the moral foundations of human rights were laid out in the Magna Carta. Nevertheless, they can be considered as being a legacy of modern civilisation. Namely, World War II claimed numerous lives and devalued the human right to life, thus encouraging the Allies to state the issue of the protection of human 
beings, and their personality and integrity, as an integral part of the Atlantic Charter and the United Nations Declaration while the War was still in progress. This concept of rights is particularly expressed through the Charter of the United Nations, which is imbued with the idea of the protection and enhancement of human rights.

However, it was not distinctly stated anywhere in the Charter which rights constituted the body of human rights, which made it necessary to pass a declaration that would compensate for all these drawbacks. After three years of work, the Universal Declaration of Human Rights was adopted on 10 December 1948. The Declaration includes conventional civil and political rights, as well as social and economic rights, all of which are becoming a significant factor in western legal systems.

However inalienable human rights may be, they were not introduced into the body of the 1950 European Convention on Human Rights which is, unfortunately, why they are still marginalised and their flagrant violation still tolerated by the European Union. The reason for that lies within several factors, the two most significant being an insufficiently-developed awareness of the necessity and irreplaceability of these rights, both for nation states and the European Union; and the lack of the material means by which these rights could be realised.

\section{Conditions for the enhancement of social and trade union rights}

Economic, social and cultural rights originate from riots, revolutionary ideas and the need for social and economic safety. They are expensive, since it is necessary to have a stable social system with a strong economic foundation before they can be realised. Such rights have been proclaimed by the European Union and countries have the obligation to provide all necessary conditions for their realisation. Hence, it is necessary to provide for the political safety and economic stability of a country as a precursor to anything else. Only by establishing such a social and state-sponsored system, and under the direct influence of global politics, through strong political propaganda and considerable pressure, may a society acquire the ability to mature 'spontaneously' and to develop an awareness of the necessity of these rights.

In addition, social and political crisis can also affect the development of the awareness of social and economic rights. Here, we may point to the significance and impact of the social protests in Greece, both as regards Greece itself as well as for the global lessons they hold. Experience has shown that rights have been marginalised for a number of years but it has been realised, unfortunately due to numerous strikes and demonstrations, that, where such rights are not proclaimed, recognised and realised within a social system, society cannot function. The poverty rate rises, as does the rate of illness, illiteracy and unproductiveness, all of which brings a society to its eventual weakening and disappearance.

Regarding the level of financial support for these rights, with their realisation as a policy goal it is important to emphasise their cost. A country is expected to provide an increase in public expenditure, and proactively to forecast and launch proper measures that will facilitate such an increase, thus bringing about an increase in gross revenues, by giving subsidies and launching social programmes and social welfare provision for the poor, as well as for the unemployed and people with disabilities. This is a tough mission nowadays. 
Nevertheless, the body of these rights includes those that can be realised by government withdrawal; more precisely, the respect for personal property and the assets of an individual, as well as respect for their right to seek employment and their right to work. These rights do not require any financial support by a country, but they continue to be flagrantly violated.

\section{The generations of human rights}

In the legal literature, human rights are classified into first, second and third generations of human rights. The first generation of human rights consists of political and civil rights; the second generation of human rights are economic, social and cultural rights; while the right to a clean environment and a healthy ecosystem constitute third generation rights.

Economic, social and cultural rights belong to the second generation of human rights, but that does not make them any less important than the first generation of human rights. On the contrary, they are compatible and correlative: one cannot be breached without detriment to another.

The origins of human rights within the area of social and trade union rights

The most significant legal origins of our economic, social and cultural rights are the following documents:

- International Covenant on Civil and Political Rights, adopted in 1966

- International Covenant on Economic, Social and Cultural Rights, also adopted in 1966

- International Convention on the Protection of the Rights of All Migrant Workers and Members of Their Families

- International Convention on the Elimination of All Forms of Racial Discrimination

- International Convention on the Elimination of All Forms of Discrimination Against Women

- American Declaration on the Rights of Man and the Citizen

- American Declaration on Human Rights and the Additional Protocol on Economic, Social and Cultural Rights

- the European Social Charter, adopted in 1996.

The International Covenant on Economic, Social and Cultural Rights proclaims, among other rights, the right to work and the right to adequate working conditions; the right to social security; the right to protect one's family; the right to health; and the right to education. By the interpretation of legal norms in the context of these rights, and keeping in mind the general correlation and unbreakable bonds of all human rights, these rights may also be realised through civil and political rights, i.e: the right to freedom of thought, conscience and religion, especially through the right to self expression; the right to peaceful assembly and association; and the right to the peaceful enjoyment of property.

The real extent to which these rights are actually realised, and whether they are only proclaimed perfunctorily, i.e. in order to meet international standards, is a subject which may be considered from country to country. However, a general conclusion is that, 
subsequent to 2008 and the occurrence of global economic crisis, and with the use of business decline and the increased need for cheap labour as excuses, many global companies have flagrantly violated these rights without having had sanctions taken against them.

\section{Social and trade union rights as a part of human rights in the Republic of Serbia}

The Republic of Serbia, as a legal successor of the Socialist Federal Republic of Yugoslavia (SFRJ), has ratified some of these conventions and protocols aiming at the protection of human rights within the area of social rights and economic rights, and encompassing trade union rights. The Republic of Serbia has ratified the International Covenant on Economic, Social and Cultural Rights twice - in July 1971 (Službeni list SFRJ - International Agreements No 7/71); and in October 2000 - thus undertaking the obligation to report to the UN on all measures taken and results achieved in ensuring that the rights recognised in the International Covenant are respected.

Despite the Republic of Serbia having ratified the International Covenant, and that international human rights standards have been declaratorily met in many regulations, one can come to the conclusion that the law of the Republic of Serbia still does not guarantee a sufficiently good protection of human rights. This is the result of structural drawbacks in the legal system as well as breaches of international standards in the area of trade union organisation and labour rights. There are numerous decisions of the European Court of Human Rights which speak in favour of this, and by which the Republic of Serbia has been held accountable for breaches of such standards.

Only by the active engagement of the country with all necessary systems of political support, both material and moral, can social and trade union rights be realised primarily as rights which are inalienable.

The impact of politics and political power on these rights is an inexhaustible subject and the Republic of Serbia is, unfortunately, yet another example. These rights should be treated as a priority and realised through proper strategies and a government plan; but it is true that they are marginalised here as well.

Thus, the right to work is based on the government having the obligation to provide the conditions necessary for citizens to be able to seek employment and work opportunities. An earlier theory of socialist legal systems was based on the idea that the country had the obligation to find work for its citizens. However, in more recent conditions, we can see that the obligation these days goes as far only as creating the necessary working conditions and helping citizens find employment, and not actually to establish work for them.

If we analyse the material and political conditions that have a direct impact on one country's economic circumstances, we cannot claim that the right to work is not also under their direct influence. Namely, political will is the factor upon which every final decision lies, and the one that is in charge of the distribution of the means to more or less preferred departments and all for the purpose of creating a better image on the global economic scene. To be more precise, the more secure and stable the government is, and the more political stability with clear vision that the country can offer, the more accessible foreign investment will be. With that, new job opportunities will be offered, thus realising people's rights fairly well. 
Nevertheless, a clear attitude and vision, as well as precise supply and demand, and solid legal regulations from which not only investors can benefit but also those who work there, cannot be attributed to any of the governments that have been in power so far.

Strongly affected by the lack of financial resources, many domestic companies have been taken over by foreign corporations without their making even any initial commitment to secure the rights of the workers, not to mention implementing a later such commitment in practice. Angry unions, where they were well-organised and unified, did start to commence organising strikes, although these have tended be 'silenced' shortly afterwards by the making of all kinds of promises that were never then kept. After these unsuccessful 'agreements', a number of workers initiated judicial proceedings, both in the courts of law of Serbia and the courts of competent jurisdiction outside our country, in order to realise the rights they had gained through many years' work and for which both the government and the political elite had shown such utter disregard.

Domestic judicial proceedings take place over a long period of time, which represents a direct violation of the principle of rapid access to justice embodied in labourbased judicial proceedings as well as other rights that constitute the body of human rights. Furthermore, if we go through the decisions of the European Court in Strasbourg, we can see clearly that the Republic of Serbia has been held responsible for violations of workers' rights to enjoy their property (concerning the payment of wages in companies in insolvency proceedings). As such, it is under the obligation to reimburse all injured parties. It is important to point out that, in some cases, sufficient conditions have not been fulfilled necessary to start judicial proceedings in the European Court of Human Rights but, the way things currently are, more decisions in favour of employees can be expected, primarily regarding the violation of their rights to social security and to just and adequate working conditions. A great number of companies in the Republic of Serbia, including those with state capital behind them, have flagrantly violated these rights and silenced the trade unions.

There is also a realistic possibility of stating the amount of responsibility that the Republic of Serbia indirectly holds for allowing labour to take place in the shadow economy. Namely, a large number of people work without any of their social or economic rights being secured. Most of all, their working conditions are inhumane: people work without any protective equipment and with no prior education about their working conditions, without regular income and almost always without any social benefits or membership of any trade union organisation. Employees are directly dependent on the goodwill of the employer, while inspection authorities neither control nor take sanctions in respect of any of the existing violations. Namely, the political will of the state in the Republic of Serbia is currently such that it allows employers the arbitrary dismissal of their employees, even though they are not registered and have not signed any kind of employment contract which would allow them to protect their social and labour rights. Furthermore, the right of the inspection authorities to control the employer, as well as for the processes of trade union organisation to be asserted, is becoming weaker with time. 
Being under great political pressure, and also for the sake of maintaining its parliamentary majority, every single member of the governing coalition goes along with their 'business partners' and their own departments, allowing neither their own actions nor the actions of others to come under scrutiny. However, the election campaign, together with some changes that have recently taken place on the political scene, has started to see the picture being stirred up a little.

The right to work also encompasses the right, with the help of the public authorities, to additional training, reskilling and any further improvement of employees, as well as the right to equal and just working conditions, while every employee has the right to income reimbursement, to healthy and safe working conditions, to paid leave and to leisure time.

Looking at the current situation in the Republic of Serbia, we cannot claim that such rights have been realised here. After the political changes that took place in 2001, the Republic of Serbia developed a series of social programmes to stimulate employment and support the education of its citizens, but things have been somewhat different in reality. A large number of national employment agencies have been reduced to almost nothing other than the maintenance of statistical records on the number of registered and unlisted citizens looking for work, neither making any real suggestions nor providing them with any work engagements. Another problem is that, due to the influence of political will and the political parties in power, acquaintances, party members and various individuals under patronage obtain jobs in certain departments, without any prior public advertisement of a situation being vacant. By going through the work files of those who are employed and those who have applied for posts but who have not been selected, it would be possible clearly and explicitly to establish elements of the flagrant violation of second-generation human rights. However, the only reaction of the state government and the political majority is silence.

Trade unions have the legal authority to organise and take any necessary action, primarily regarding the enhancement and realisation of the rights to which they are entitled, but they are lethargic. They possess neither the will nor the means to bring about any changes because their own members, taught by personal experience and that of their predecessors, share the opinion that any form of 'going public' and getting out of the groove of the political system can only make matters worse than they currently are, and that the final outcome would be further suffering under the oppression of the more politically influential. And there is no legal aid one can rely on.

Furthermore, the Republic of Serbia, which used to be a communist, single-party state, lacks the spirit of freedom and independence of trade union association and organisation. Namely, the unions that are organised in the Republic of Serbia are more or less politically charged. Being a member of certain trade unions represents direct support for a particular political party which, sadly, pays those unions and their representatives 'under the table', whereas the true supporters of the ideas of enhanced labour and social rights end up being marginalised and ridiculed. If we look back on the 1990 s and the great political change that took place in 2000, we can notice that, back then, there existed so-called trade union 'believers' and 'non-believers' in the regime who, by order of their superior political leaders, organised mass strikes or else sup- 
pressed them using different types of threat to stop or obstruct them. Despite the change in the political system, the situation has, to this day, remained the same.

Trade union organisation and rights are flagrantly violated, marginalised and obstructed in the Republic of Serbia, despite the system of social democracy being established by the Constitution of the Republic of Serbia some twenty years ago. Democracy has been embodied in some other forms of freedom, but certainly not in the freedom of trade union association and organisation, which is equal to the right to freedom of expression, the legacy of habeas corpus.

It goes without saying that strong trade unions and their organisation remain a significant element of democratic society, but it will take employees some time to develop the awareness that trade union association and organisation can, and should, be about fighting for their rights and facilitating the realisation of human rights. Due to the difficult social conditions, in which $95 \%$ of the population live a hand-to-mouth existence, these have been forgotten about and are not a current enough issue to be brought to our political scene. Employees should bear in mind that they not only have the right to work, but also the right to choose how they work, in what conditions, what is their salary and what are the social benefits. Unfortunately, trade unions have also forgotten certain elements and foundations of their organisation.

\section{Conclusion}

One can come to the general conclusion that certain rights, which have been proclaimed and ratified under various conventions and covenants, are flagrantly being violated in the Republic of Serbia. For the most part, they are not realised in practice, and usually only mentioned in the form of declarations during election campaigns.

However, if the state government realised that, by determining a good foundation for social and economic rights, they would pave the way to the west for their country, and hence commenced the realisation of social programmes which gave full support to non-political, independent trade union organisations, then, on the basis of co-operation between employer, trade union and government, intolerance and social conflict would be brought almost to a minimum and human rights would be realised.

Via the direct violation of the social and economic rights of its citizens, a nation state, as a political correlate of a politically-prevalent idea, shows its own irresponsibility and disregard for its citizens and voters, thus paving the way for its certain disaster. Namely, even great, economically much stronger and more stable political systems are not immune to social conflict and instability. The current situation on the political scene of the Republic of Serbia - where everything is left unsaid, where foreign investments only come and go, and where there are no new job openings while, at the same time, employees are every day losing their jobs and the rights they gained through years of work - can only lead to the question being posed as to who benefits from this kind of right-less situation and from providing all the necessary conditions for social unrest?

Namely, the right to work is a fundamental factor in social safety, providing employees and households with income and thus securing economic stability and independence for families. Only when an individual is economically independent, without any considerable oscillations in their standard of living, which is something that can 
only be accomplished by the provision of regular income and social benefits, can we start talking about the possibility of their further mental and spiritual improvement. A society and its political system are healthy when they consist of individuals who realise and fulfil their own needs, when they have the time and the means to become accomplished and consequently participate in social community. This can be achieved only by the realisation of economic and social rights.

The moment those rights which fully concern an individual and have a negative impact on their personal life, and which include all the rights discussed here, become endangered or are violated, the individual becomes self-engrossed and starts to neglect proclaimed social standards. The society, the country and the political system start to fall apart.

\section{References}

Avramov, S and M. Kreća (2003) Međunarodno javno pravo Beograd.

Dimirijević, V, M. Paunović and V. Đerić (1997) Ljudska prava-udžbenik Beograd: Beogradski centar za ljudska prava.

Dimirijević, V, D. Popović, T. Papić and V. Petrović (2006) Međunarodno pravo ljudskih prava Beograd.

Krivokapić, B (2003) Evropska socijalna povelja Beograd.

Krivokapić, B (2006) Međunarodno pravo koreni, razvoj, perspektive Beograd.

Nikolić, L. D (2005) Sloboda izražavanja u teoriji, zakonima i praksi nacionalnih $i$ Evropskog suda pravde Beograd.

Obradović, K and M. Paunović, M (1996) Pravo ljudskih prava-nove teme Beograd.

Paunović, M (2004) Osnovi ljudskih prava-izvornik i pojmovnik Beograd.

Paunović, M and S. Carić (2006) Evropski sud za ljudska prava-osnovna načela i tok postupka Beograd.

Paunović, M, B. Krivokapić and I. Krstić (2007) Osnovi međunarodnih ljudskih prava Beograd.

Služba za ljudska i manjinska prava Vlade Republike Srbije, Svete Evrope (2008) Odluke i presude Evropskog suda za ljudska prava donete u odnosu na Republiku Srbiju za period mart 2004-mart 2008 Beograd.

Beogradski centar za ljudska prava (2002) Ljudska prava u Jugoslaviji 2001: pravo, praksa i pravna svest u Saveznoj Republici Jugoslaviji i međunarodni standardi ljudskih prava Beograd. 